\title{
Is progesterone the key regulatory factor behind ovulation rate in sheep?
}

\author{
P.M. Bartlewski ${ }^{\text {a,*}}$, J. Sohal ${ }^{\text {a }}$, V. Paravinja ${ }^{a}$, T. Baby ${ }^{\text {a }}$, M.E.F. Oliveira ${ }^{\text {b }}$, \\ M. Murawski ${ }^{\text {c, }}$, T. Schwarz ${ }^{\text {d }}$, D.A. Zieba ${ }^{c}$, D.H. Keisler ${ }^{\text {e }}$

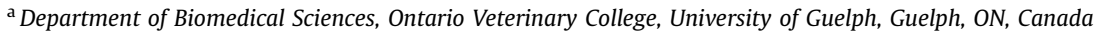 \\ ${ }^{\mathrm{b}}$ Department of Preventative Veterinary Medicine and Animal Reproduction, College of Agricultural and Veterinary Sciences, \\ São Paulo State University, Jaboticabal, SP, Brazil \\ ${ }^{\mathrm{c}}$ Department of Animal Biotechnology, Agricultural University of Kraków, Cracow, Poland \\ d Department of Swine and Small Animal Breeding, Agricultural University of Kraków, Cracow, Poland \\ e Animal Sciences Research Center, University of Missouri, Columbia, MO, USA
}

\section{A R T I C L E I N F O}

\section{Article history:}

Received 22 March 2016

Received in revised form 27 May 2016

Accepted 17 June 2016

\section{Keywords:}

Sheep

Ovulation rate

Progesterone

FSH

Ultrasonography

\begin{abstract}
A B S T R A C T
Ovarian antral follicles in the ewe grow in an orderly succession, producing 3 to 4 waves per estrous cycle. In prolific sheep, some large antral follicles from the second-to-last wave of the estrous cycle are added to the ovulatory follicles emerging just before estrus to give a higher ovulation rate; it is feasible that regression of these follicles is prevented by an increase in serum concentrations of FSH or LH pulsatility at proestrus. Prolific sheep tend to have a shorter luteal phase than nonprolific ewes and there is a great deal of evidence that luteal progesterone $\left(\mathrm{P}_{4}\right)$, in addition to regulating $\mathrm{LH}$ release, may govern the secretion of FSH heralding the emergence of follicular waves. The specific purpose of this study was to determine whether or not extending the duration of the luteal phase in prolific sheep to that typically seen in nonprolific breeds would alter the follicle wave dynamics and ovulation rate. In 2 separate experiments, exogenous $\mathrm{P}_{4}$ ( $7.5 \mathrm{mg}$ per ewe intramuscularly) was administered on day 11 at PM and day 12 at AM (day $0=$ first ovulation of the interovulatory interval studied) in moderately prolific Rideau Arcott $\times$ Polled Dorset ewes (experiment $1, \mathrm{n}=8$ ) and highly prolific Olkuska ewes (experiment $2, \mathrm{n}=7$; TRT), whereas the equinumerous groups of animals served as controls (CTR). Transrectal ovarian ultrasonography was performed daily, and jugular blood samples were drawn twice a day from day 9 until the next ovulation. Progesterone injections resulted in relatively uniform increments in serum $\mathrm{P}_{4}$ levels, but the mean duration of the interovulatory interval did not differ $(P>0.05)$ between TRT and CTR groups of ewes in either experiment. The mean ovulation rate post-treatment was $1.6 \pm 0.2$ vs $3.2 \pm 0.4$ (experiment $1, P<0.001$ ) and $3.2 \pm 0.8$ vs $4.0 \pm 1.0$ (experiment $2, P>0.05$ ) in TRT vs CTR, respectively. The number and percentage of ovulating follicles from the penultimate wave of the interovulatory interval studied was $0.25 \pm 0.16$ vs $1.75 \pm 0.45(P<0.01)$ and $25.0 \pm 16.4 \%$ vs $75.0 \pm 16.4 \%(P<$ $0.05)$ in experiment 1 , and $0.50 \pm 0.30$ vs $1.60 \pm 0.40(P<0.05)$ and $13.8 \pm 9.0 \%$ vs $53.4 \pm$ $16.7 \%(P<0.05)$ in experiment 2 , for TRT vs CTR, respectively. In summary, administration of $\mathrm{P}_{4}$ at the end of diestrus decreased the incidence of ovulations from the penultimate wave of the estrous cycle in both the moderately and highly prolific strains of sheep, but it reduced the ovulation rate only in moderately prolific ewes.
\end{abstract}

(c) 2016 Elsevier Inc. All rights reserved.

\footnotetext{
* Corresponding author. Tel.: 519-824-4120x53330; fax: 519-767-1450.

E-mail address: pmbart@uoguelph.ca (P.M. Bartlewski).
} 


\section{Introduction}

Sheep have a broad spectrum of fertility, which makes them a perfect model species to study the factors controlling ovarian function and ovulation rate. Lamb productivity of the ewe is genetically predetermined and it can vary among breeds from $\sim 1$ in typically monovular breeds (eg, Merino del Pais) to $>5$ in the carriers of fecundity genes such as FecB or Booroola genotypes [1,2]. However, in spite of the fact that products of certain genes may program this tremendous biodiversity [3], the hormonal control of ovarian follicle kinetics and ovulation rates in sheep is not completely understood. The physiological regulation of ovulatory follicle development remains unclear [1], and continued investigations into the mechanisms governing ovulation and fertility have been central in reproductive biology across species [3].

Numerous studies have been conducted in an attempt to determine the regulation of ovarian follicular development in domestic animals, including small ruminants $[1,4,5]$. Antral follicles in the ewe emerge in an orderly succession, producing 3 to 4 follicular waves per 17-day estrous cycle $[1,2]$. Each wave consists of 1 to 4 follicles attaining an ostensibly ovulatory size before regression or ovulation and is preceded by a transient rise in FSH secretion [1,2]. From earlier studies of temporal relationships between FSH secretory patterns and wave emergence in ewes, it appears that FSH controls the initial stage of antral follicle growth, from emergence to the end of the growth phase, but ensuing follicular development and demise are independent of FSH $[1,2,6]$. Recurrent pulses of LH also promote the growth of large ovine follicles and prolong the static phase of their lifespan [7]. In prolific ewes, some large antral follicles from the penultimate wave of the estrous cycle are added to the ovulatory follicles emerging just before estrus to give a higher ovulation rate $[1,2,8,9]$. Prolific sheep tend to have a shorter luteal phase than nonprolific breeds, and there is a great deal of evidence supporting the notion that luteal progesterone $\left(\mathrm{P}_{4}\right)$, in addition to regulating pulsatile release of $\mathrm{LH}$, may govern the secretion of $\mathrm{FSH}[4,5]$. Therefore, it is feasible that the onset of regression of some penultimate wave follicles in prolific ewes is delayed or prevented by the next increase in serum concentrations of FSH or gradual increase in LH pulsatility at proestrus.

Thus, our general supposition was that luteal $\mathrm{P}_{4}$ was the driving regulatory force behind ovulation rates in ewes. To test if this theory stands true, our study was designed to monitor antral follicle development and assess the ovulation rate with transrectal ultrasonography or diagnostic laparoscopy in cyclic ewes in which elevated, midluteal phase levels of $\mathrm{P}_{4}$ were maintained through administration of the exogenous gestagen at the expected end of diestrus. We hypothesized that maintaining high $\mathrm{P}_{4}$ concentrations for 1 to 2 more day(s), as seen in nonprolific breeds of sheep $[1,2,10-12]$, would alter follicular wave development and ovulation rate in prolific sheep to resemble those in nonprolific ewes. Two independent experiments, with identical designs, were conducted on a moderately prolific crossbred ewes (Rideau Arcott $\times$ Polled Dorset crosses), with 2 to 3 ovulations per cycle ([13]; experiment 1), and on a highly prolific sheep strain (Olkuska breed), in which certain individuals were the carriers of high fecundity genes and all animals had consistently produced 3 to 6 lambs per breeding ([14,15]; experiment 2).

\section{Materials and methods}

All experimental procedures performed on live animals were in compliance with the guidelines of the Canadian Council on Animal Care or with the European Community (EC) directives for animal experimentation and had been formally approved by the local animal care or bioethics committees.

\subsection{Experiment 1}

This experiment was performed during the breeding season (October-November) on 16 clinically healthy, nulliparous Rideau Arcott $\times$ Polled Dorset ewes aged 11 to 28 mo, with a mean ( \pm standard error of the mean [SEM]) body weight of $67.9 \pm 8.2 \mathrm{~kg}$. Animals were housed at the Ponsonby Research Station near Guelph, ON, Canada (latitude: $43^{\circ} 83^{\prime} 30^{\prime \prime} \mathrm{N}$ ) under natural conditions of photoperiod and ambient temperature. The ewes were kept in sheltered dry lots, fed daily maintenance rations of alfalfa pellets and hay, with water and cobalt-iodized salt licks available ad libitum. Estrus was detected with a 2-electrode vaginal impedometer (Electronic Oestrus Detector; Dramiński Electronics in Agriculture, Olsztyn, Poland) recording changes in vaginal mucous impedance that had been validated for the present application in sheep [16,17]. Two intramuscular injections of $2 \mathrm{~mL}$ of Prostaglandin $\mathrm{F}_{2}$ alpha $\left(\mathrm{PgF}_{2 \alpha}\right)$ (5 mg/mL; Lutalyse; Pharmacia Animal Health, Orangeville, ON, Canada) were initially given $9 \mathrm{~d}$ apart to 22 animals. Detection of estrus continued until the vaginal mucus impedance declined below $40 \Omega$ (onset of luteolysis) and then increased above $40 \Omega$ (ovulation = day 0 ) in the first 16 ewes. Subsequently, the ewes were randomly allocated to the treatment and control groups $(n=8$ in each group). The treatment group animals received 2 injections of $7.5 \mathrm{mg}$ of progesterone ( $\mathrm{P}_{4}$; Chiron Founding Pharmacy; Guelph, ON, Canada) in $0.5 \mathrm{~mL}$ of corn oil intramuscularly, in the evening of day 11 and in the morning of day 12; control ewes received injections of the vehicle only (sterilized corn oil). Corn oil was used as the vehicle to allow for a slow release of $\mathrm{P}_{4}$ after the treatments applied $12 \mathrm{~h}$ apart [4].

Blood samples were drawn twice daily via jugular venipuncture into $10-\mathrm{mL}$ coagulant-free vacutainers (Becton Dickinson, Rutherford, NJ, USA). The samples were permitted to clot for 12 to $24 \mathrm{~h}$ at room temperature and then centrifuged at $1,500 \times g$ for $10 \mathrm{~min}$. Serum was harvested and stored at $-20^{\circ} \mathrm{C}$ until analyses at the later date.

Daily transrectal ultrasonography of ovaries used a portable Aloka 900-SSD echo-camera (Aloka; Tokyo, Japan) connected to a rigid 7.5-MHz biplane rectal transducer. The linear-array component of this transducer was used to visualize all antral follicles $\geq 2 \mathrm{~mm}$ in diameter and luteal structures. All images were displayed on the viewing screen of the echo camera at magnification $\times 1.5$ to $\times 2$, and the relative position of individual antral follicles was sketched on ovarian charts. In addition, all ultrasonographic images were recorded on a DVD recorder 
(DVR-510H; Pioneer Electronics of Canada, Oakville, ON, Canada) for subsequent analyses of ovarian data. Daily ultrasonographic examinations of ovaries were carried out by the same experienced operator from the time of the second $\mathrm{PgF}_{2 \alpha}$ injection until ovulation detection (day 0 ) and again from day 9 until the next ovulation of the interovulatory interval studied. Ovulations were detected by a disappearance of large antral follicles ( $\geq 5 \mathrm{~mm}$ in size) followed by a formation of corpora hemorrhagica approximately $24 \mathrm{~h}$ after follicle rupture [18]. Seven days after the estrus post-treatment, all animals underwent laparoscopic examinations of ovaries using the Tele Pack Vet X Led video endoscope (Karl Sorz GmbH \& Co KG, Tuttlingen, Germany) to enumerate corpora lutea. Approximately 10 min before endoscopy, each ewe was given an intramuscular injection of $0.4 \mathrm{~mL}$ of Rompun ( $20 \mathrm{mg} / \mathrm{mL}$ of xylazine; Bayer, Toronto, ON, Canada) and at the start of the procedure, each animal received 1.5 to $2.0 \mathrm{~mL}$ of local subcutaneous (s.c.) anesthetic (1\% lidocaine hydrochloride; Zoetis, Kirkland, QC, Canada) at the sites of trocar punctures in the abdominal wall.

Serum samples were analyzed by the Prairie Diagnostic Services, University of Saskatchewan, Saskatoon, SK, Canada, using validated RIAs to determine concentrations of FSH [19], $\mathrm{P}_{4}$ [20], and estradiol (E2; [21]). The sensitivities of assays defined as the lowest concentration of a hormone that was capable to significantly displace radiolabeled hormone from the binding with the primary antibody were $0.1 \mathrm{ng} / \mathrm{mL}, 0.03 \mathrm{ng} / \mathrm{mL}$, and $1 \mathrm{pg} / \mathrm{mL}$, for $\mathrm{FSH}, \mathrm{P}_{4}$, and $\mathrm{E}_{2}$ assays, respectively. For reference sera with mean FSH concentrations of 0.92 and $3.45 \mathrm{ng} / \mathrm{mL}$, the intra-assay coefficients of variation (CVs) were $6.6 \%$ and $9.3 \%$, respectively. For reference sera with mean $\mathrm{E}_{2}$ concentrations of 8.1 and $21.2 \mathrm{pg} / \mathrm{mL}$, the intra-assay CVs were $8.6 \%$ and $11.1 \%$, respectively. For reference sera with mean $\mathrm{P}_{4}$ concentrations of 0.27 or $1.23 \mathrm{ng} / \mathrm{mL}$, the intra-assay and interassay CVs were $6.3 \%$ and $5.1 \%$ and $13.0 \%$ and $3.8 \%$, respectively. The ranges of standards were as follows: (1) ovine FSH (oFSH): 0.06 to $16.0 \mathrm{ng} / \mathrm{mL}$ (oFSH-SIAFP-RP-2); (2) $\mathrm{E}_{2}-17 \beta$ : 1.0 to $50 \mathrm{pg} / \mathrm{mL}$; and (3) $\mathrm{P}_{4}: 0.03$ to $10.0 \mathrm{ng} / \mathrm{mL}$.

\subsection{Experiment 2}

The second experiment was conducted during the month of November in the field research station of the Agricultural University of Kraków, Poland, situated in Bielany (latitude: $50^{\circ} 03^{\prime} 31^{\prime \prime} \mathrm{N}$ ), and it employed 14 multiparous Polish Olkuska ewes aged 3 to $5 \mathrm{yr}$ and weighing between 52 and $73 \mathrm{~kg}$. The animals were housed in a barn under natural conditions of light and ambient temperature. All ewes received daily food rations formulated to provide $100 \%$ of nutritional requirements [22]; water and mineral licks were available ad libitum. Among 7 animals allocated to each group, 2 ewes had been identified as carriers of a high fecundity gene (F-gene homozygous), 3 were heterozygous and 2 were noncarriers of the F-gene [14]. Experimental design, various methods of data acquisition and drugs used were all identical to those described for experiment 1, except for the procedures and pharmaceuticals detailed in the following paragraph.

Progesterone for injections was purchased from Sigma Life Science (Sigma-Aldrich, St. Louis, MC, USA). Estrus was detected twice daily ( $2 \times 20 \mathrm{~min})$, starting $2 \mathrm{~d}$ after the second injection of $\mathrm{PgF}_{2 \alpha}$ (Lutalyse; $10 \mathrm{mg} / \mathrm{ewe}$ ), with a fertile ram fitted with an apron preventing penetration during mounting. Transrectal ovarian ultrasonography used the Aloka ProSound 2 scanner (Hitachi Aloka Medical; Tokyo, Japan) equipped with a stiffened (plastic extension) 7.5-MHz linear-array transducer. Ultrasound images of both ovaries were digitally acquired and recorded directly on a computer (at a resolution of $640 \times 480$ pixels). Ewe undergoing endoscopy received a single intramuscular injection of $0.4 \mathrm{~mL}$ of Nefrasin vet. (containing $20 \mathrm{mg} / \mathrm{mL}$ of xylazine hydrochloride; aniMedica Polska, Gdynia, Poland) and local s.c. injections of 1 to $1.5 \mathrm{~mL}$ of polocainum hydrochloricum (2\%) with adrenaline (0.005\%; Biowet, Drwalew, Poland). Blood sera were assayed by the Animal Sciences Research Center at the University of Missouri. All samples were analyzed for $\mathrm{P}_{4}$ concentrations in a single assay [23] with the standard curve range from 0.005 to $40 \mathrm{ng} / \mathrm{mL}$ and detection limit of $0.1 \mathrm{ng} / \mathrm{mL}$; an intra-assay CV was $2.0 \%$. Estradiol concentrations were determined with 3 assays [24]; intra-assay and interassay CVs were $4.3 \%$ and $4.4 \%$, respectively; assay range was 0.05 to $12 \mathrm{pg} / \mathrm{mL}$ and minimum detectable concentration was $0.01 \mathrm{ng} / \mathrm{mL}$. Serum concentrations of FSH were determined in a single RIA [24] with sensitivity of $0.1 \mathrm{ng} / \mathrm{mL}$ and concentrations of a standard (oFSH AFP5679c) ranging from 0.1 to $15.0 \mathrm{ng} / \mathrm{mL}$; an intra-assay CV was $2.0 \%$.

\subsection{Data analysis}

A cycle detector program (or the threshold adaptive technique [25]) was used to determine the peaks of successive $\mathrm{FSH}$ and $\mathrm{E}_{2}$ fluctuations during the period from days 11.5 to 16.5 ; the number and concentrations of peaks detected in individual ewes were computed. This method uses an iterative algorithm that scans serial data to identify increases and decreases greater than a preset threshold value (determined using intra-assay CVs). One complete cycle or fluctuation (nadir-to-peak-to-nadir) is regarded as an increase that is greater than threshold followed by a decrease, which is also greater than threshold.

A follicular wave was defined as a group of follicles that grew synchronously from 2 or $3 \mathrm{~mm}$ to $\geq 5 \mathrm{~mm}$ in diameter before regression or ovulation [2]. The day of wave emergence, the number of all follicles, and the number and proportion of ovulatory follicles in the penultimate and last wave of the estrous cycle studied were noted. In addition, all antral follicles of the wave were analyzed for their maximum diameter, duration of the growth phase, static phase and regressing phase, as well as the mean growth and regression rate. The growing phase was defined as the time taken to grow from 2 to $3 \mathrm{~mm}$ to the maximum diameter attained before regression or ovulation, and the regressing phase was the number of days taken to regress from its maximum diameter to $2-3 \mathrm{~mm}$. The time between the end of growth and the onset of regression or ovulation was the static phase of follicular lifespan. The number and diameter of all ovulating follicles were recorded.

All data sets were initially screened for outliers using the Dixon Q-test. Single-time point mean values were compared between the treated and control ewes by 
Student $t$ test. For 2 data sets with nonhomogenous variances, the Mann-Whitney rank sum test was performed. Statistical differences among serial hormonal and ovarian data were assessed by 2-way repeated-measures analysis of variance (ANOVA, general linear model procedures) using SigmaPlot (version 11.0 for Windows, 2010 Systat Software, Inc Richmond, CA, USA). Proportions were compared by a $\chi^{2}$-test (Brandt-Snedecor formula [26]). The results were expressed as mean \pm SEM, and the statistical significance was regarded as $P<0.05$. The present experiments used different ultrasonographic equipment and hormone assays, and so no direct comparisons of data were made between breeds.

\section{Results}

\subsection{Experiment 1}

Mean serum concentrations of $\mathrm{P}_{4}$ in the treated ewes increased by $1.42 \pm 0.36 \mathrm{ng} / \mathrm{mL}$ and $1.24 \pm 0.49 \mathrm{ng} / \mathrm{mL}$ approximately $12 \mathrm{~h}$ after the first and the second $\mathrm{P}_{4}$ injection, respectively, $(P>0.05)$. Progesterone-treated ewes (TRT) exceeded $(P<0.05)$ control animals (CTR) in circulating $\mathrm{P}_{4}$ concentrations from days 12 to 14 (Fig. 1 ). In TRT group, serum $\mathrm{P}_{4}$ concentrations decreased $(P<0.05)$ from a maximum value on day 12.5 to day 14 and again $(P<0.05)$ on day 15 , whereas $\mathrm{P}_{4}$ concentrations in control animals declined $(P<0.05)$ from day 11.5 to day 13.5 . There were significant main effects of the group and time for mean serum concentrations of $E_{2}$ over the period of study, but post-ANOVA analyses did not reveal significant differences over time in either group of ewes. Circulating concentrations of $\mathrm{E}_{2}$ were greater $(P<0.05)$ in TRT than those in CTR ewes on day 14.5 (Fig. 1). As with the $E_{2}$ concentrations, there were no significant differences in mean serum FSH concentrations within either group of ewes despite the significant main effect of Time. Progesterone-treated ewes exceeded $(P<0.05)$ their respective controls in the mean number of FSH peaks detected during the $5 \mathrm{~d}$ after the first $\mathrm{P}_{4}$ injection (Table 1). The first FSH peak post-treatment occurred $\sim 1$ d later $(P<0.05)$, but the peak concentration was significantly higher in TRT compared with CTR animals.

The mean ovulation rate at the beginning of the study did not differ $(P>0.05)$ between animals subsequently allocated to the treatment or control group, but the mean ovulation rate and number of corpora lutea $(\mathrm{CL})$ were lower $(P<0.001)$ in TRT compared with CTR ewes after the treatment with exogenous $\mathrm{P}_{4}$ (Table 2). One $\mathrm{P}_{4}$-treated ewe with 2 ovulations and 1 control animal with 3 ovulations detected ultrasonographically had 1 and $2 \mathrm{CL}$, respectively, during laparoscopic examination post-treatment; in all remaining sheep, the numbers of ruptured follicles and luteal structures were identical. Ovulatory follicles emerging in the penultimate wave were recorded in $25 \%$ of TRT $(2 / 8)$ and $75 \%$ of CTR $(6 / 8)$ ewes $(P<0.05)$. The total number, and the number and percentage of ovulating follicles emerging in the penultimate wave of the estrous cycle were significantly lower in TRT than those in CTR group, but the mean growth rate of all penultimate wave follicles and the diameter of ovulatory follicles were both greater $(P<0.05)$ in TRT ewes (Table 2$)$. There were no differences $(P>0.05)$ in any other characteristic of penultimate or final wave follicles between CTR and TRT ewes in experiment 1 . There were no significant differences in mean daily numbers of ovarian antral follicles (2, 4, and $\geq 5 \mathrm{~mm}$ in size) within either group of experimental animals or between the 2 groups of ewes studied except for the number of $3-\mathrm{mm}$ follicles that was greater $(P<0.05)$ in TRT than that in CTR ewes from days 15 to 17 (or from 3.5 to $5.5 \mathrm{~d}$ after the first $\mathrm{P}_{4}$ dose; Fig. 2A).

\subsection{Experiment 2}

Mean $\mathrm{P}_{4}$ concentrations increased in the treated ewes by $1.06 \pm 0.28 \mathrm{ng} / \mathrm{mL}$ and $1.45 \pm 0.40 \mathrm{ng} / \mathrm{mL}$ after the first and the second $\mathrm{P}_{4}$ injection, respectively $(P>0.05)$. In TRT ewes, serum $\mathrm{P}_{4}$ concentration decreased $(P<0.05)$ from a maximum value on day 12.5 to day 14.5 , whereas in CTR ewes, they declined $(P<0.05)$ from day 11.5 to day 15 (Fig. 1). Neither mean serum concentrations of FSH and $E_{2}$ nor various characteristics of peaks in circulating concentrations of both hormones varied between the 2 subsets of ewes except for the number of detected $E_{2}$ peaks that was nearly 2 times greater $(P<0.001)$ in TRT than that in CTR group (Table 1 ).

Two of 7 TRT ewes (29\%) and 6 of 7 CTR animals (86\%) had an ovulatory follicle(s) that emerged in the penultimate wave of the estrous cycle $(P<0.05)$. The number and percentage of ovulatory follicles emerging in the penultimate wave of the estrous cycle in Olkuska sheep were significantly greater in CTR than those in TRT ewes. In addition, the mean growth and regression rate of all follicles $\geq 5 \mathrm{~mm}$ in diameter in the penultimate wave were greater $(P<0.05)$ in TRT compared with CTR ewes (Table 2$)$. The remaining characteristics of follicles emerging in the penultimate and final wave of the interovulatory interval did not vary $(P>0.05)$ between CTR and TRT Olkuska sheep. Mean daily numbers of ovulatory-sized follicles ( $\geq 5 \mathrm{~mm}$ in diameter) decreased sharply $(P<0.05)$ from day 15 to day 17 in $P_{4}$-treated ewes (Fig. 2B). Mean daily numbers of follicles in other size categories did not vary $(P>0.05)$ either over time or between CTR and TRT ewes in experiment 2 .

\section{Discussion}

In the present study, exogenous $\mathrm{P}_{4}$ injections given before the end of diestrus in prolific ewes were intended to delay a decline in serum $\mathrm{P}_{4}$ to basal levels by 1 to $2 \mathrm{~d}$ to resemble the situation seen in less prolific, meat breeds of sheep [10-12]. Both injections were followed by an increase in serum $\mathrm{P}_{4}$ concentrations, but $12 \mathrm{~h}$ after the administration stopped, serum $\mathrm{P}_{4}$ levels began to decline. In the first experiment, mean serum $\mathrm{P}_{4}$ concentrations remained higher in the treated ewes until day 14 postovulation. Quite unexpectedly, however, circulating concentrations of $\mathrm{P}_{4}$ were numerically higher in control compared with treated Olkuska sheep (experiment 2) from 1 to $3 \mathrm{~d}$ post-treatment. These differences between the 2 experiments can be attributed to variable endogenous $\mathrm{P}_{4}$ concentrations in control Olkuska ewes (experiment 2), as 


\section{EXPERIMENT 1}
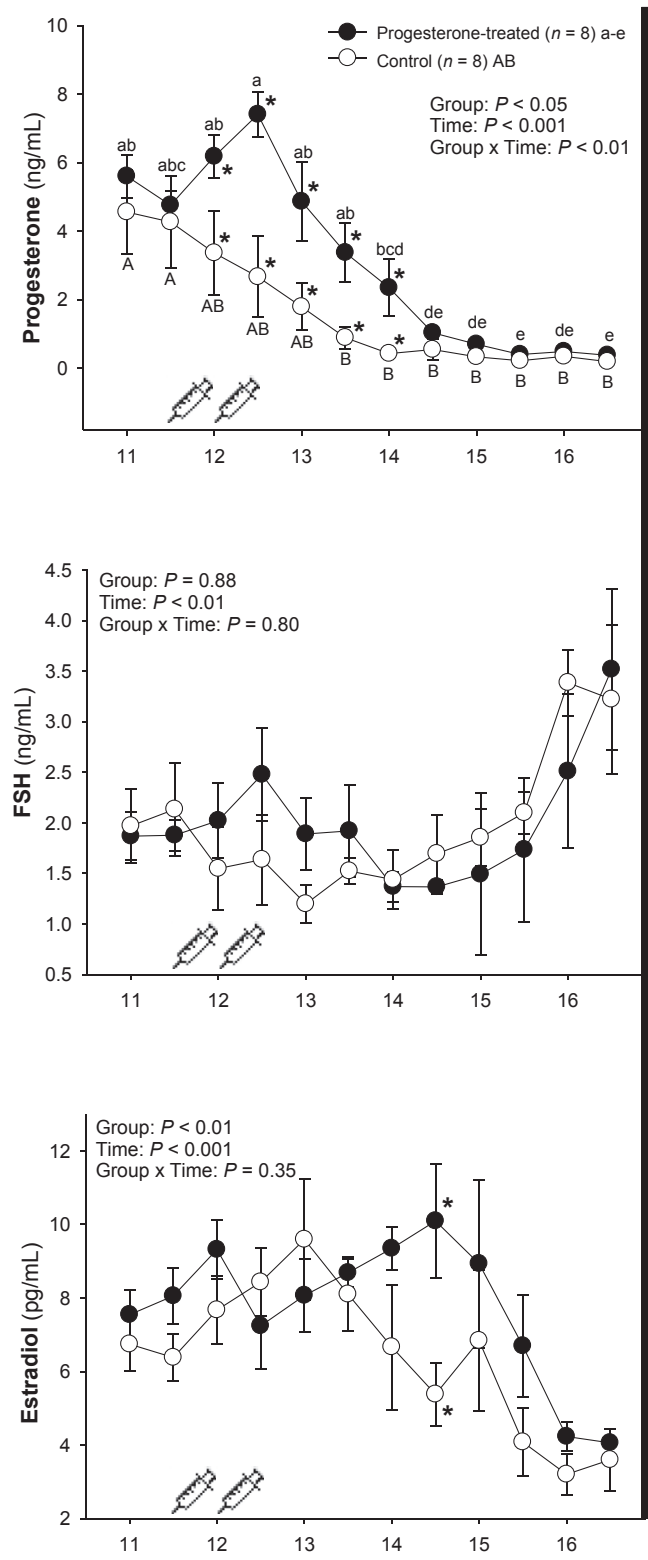

EXPERIMENT 2
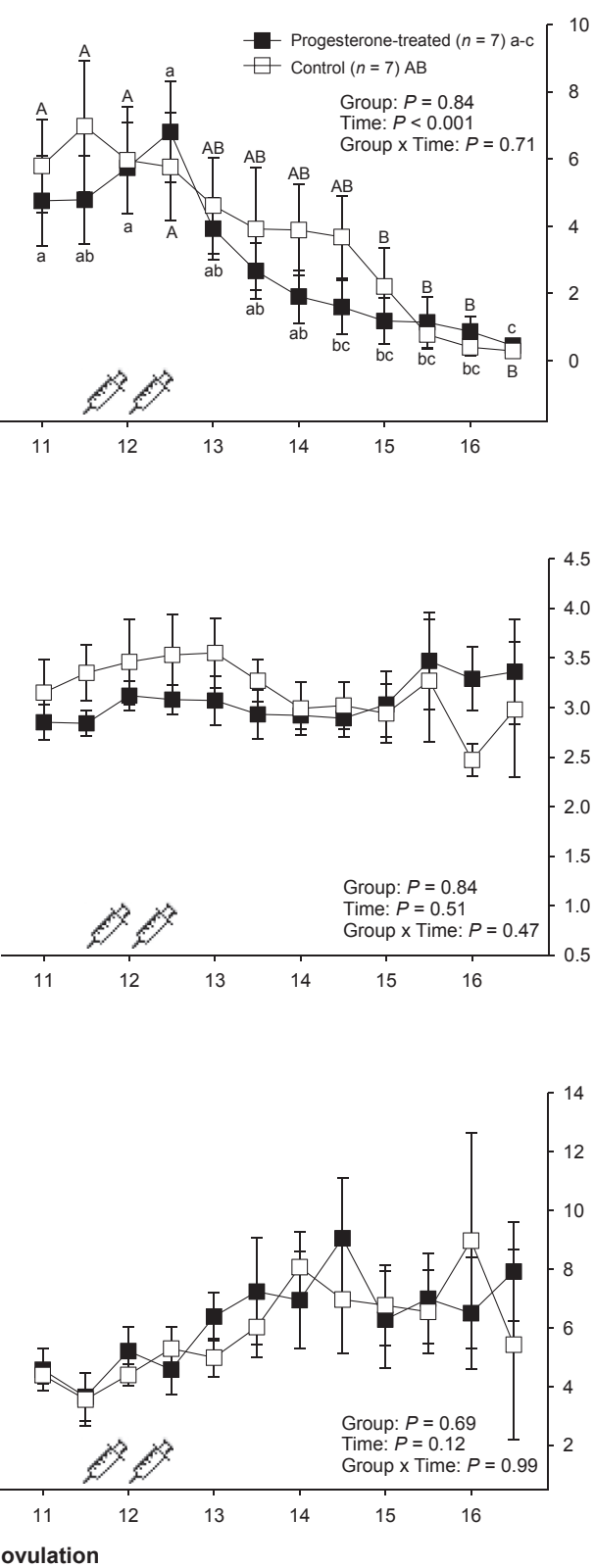

Fig. 1. Mean ( \pm standard error of the mean) serum concentrations of progesterone, $\mathrm{FSH}$, and estradiol from days 11 to 16.5 (day $0=$ first ovulation of the estrous cycle studied) in moderately prolific Rideau Arcott $\times$ Poled Dorset ewes (experiment 1 ) and highly prolific Olkuska sheep (experiment 2) that received progesterone (progesterone-treated) or vehicle injections (control) on day 11 at PM and day 12 at AM. Syringe symbols along the x-axis denote the timing of progesterone injections. Asterisks indicate the differences $(P<0.05)$ between groups, and different letters denote significant differences over time.

the pattern of changes in $\mathrm{P}_{4}$ concentrations in the treated ewes was strikingly similar in both genotypes of sheep studied. The latter suggests that elevated $\mathrm{P}_{4}$ levels at the end of diestrus may dictate and synchronize the rate of functional luteal regression in cyclic ewes. In both experiments, a decline in circulating $\mathrm{P}_{4}$ concentrations to basal levels (regarded as a period encapsulating all days on which $\mathrm{P}_{4}$ concentrations did not vary statistically from a minimal value recorded on day 16.5) occurred earlier in controls than in the treated ewes $(\sim 2.5 \mathrm{~d}$ earlier in experiment
1 and $\sim 1.5 \mathrm{~d}$ earlier in experiment 2). Induction of a prolonged luteal phase allowed us to determine the changes that $\mathrm{P}_{4}$ inflicted on circulating FSH and $\mathrm{E}_{2}$ concentrations and antral follicular development.

In experiment 1,2 injections of exogenous $\mathrm{P}_{4}$ on days 11 and 12 after ovulation were followed by FSH peaks on days $12.5,14.5$, and 16.5 , whereas untreated controls had 2 waves on days 11.7 and 15.8 postovulation. In an earlier study, administration of exogenous $\mathrm{P}_{4}$ twice daily from day 0 (ovulation) to day 4 was associated with the occurrence of 
Table 1

Characteristics of peaks in serial FSH and estradiol $\left(E_{2}\right)$ concentrations detected from days 11.5 to 16.5 in individual Rideau Arcott $\times$ Polled Dorset ewes (experiment 1) or Olkuska sheep (experiment 2) that received intramuscular progesterone (treatment) or vehicle (control) injections on day 11 at PM and day 12 at AM.

\begin{tabular}{|c|c|c|c|c|}
\hline \multirow[t]{2}{*}{ Variables } & \multicolumn{2}{|c|}{ Experiment 1 (Rideau Arcott $\times$ Polled Dorset) } & \multicolumn{2}{|c|}{ Experiment 2 (Olkuska) } \\
\hline & Treatment $(\mathrm{n}=8)$ & Control $(\mathrm{n}=8)$ & Treatment $(\mathrm{n}=7)$ & Control $(\mathrm{n}=7)$ \\
\hline \multicolumn{5}{|c|}{ Follicle-stimulating hormone peak characteristics } \\
\hline No. of peaks (days 11.5-16.5) & $2.7 \pm 0.2^{\mathrm{Ac}}$ & $1.9 \pm 0.1^{\mathrm{Bc}}$ & $2.8 \pm 0.3$ & $2.4 \pm 0.4$ \\
\hline \multicolumn{5}{|l|}{ Time of occurrence } \\
\hline Peak 1 & $12.5 \pm 0.0^{\mathrm{ac}}$ & $11.7 \pm 0.3^{\mathrm{bc}}$ & $12.2 \pm 0.3$ & $12.0 \pm 0.3$ \\
\hline Peak 2 & $14.4 \pm 0.4^{\mathrm{a}}$ & $15.8 \pm 0.3^{b}$ & $14.1 \pm 0.7$ & $14.5 \pm 0.7$ \\
\hline Peak 3 & $16.3 \pm 0.2$ & ND & $15.1 \pm 0.7$ & [14.5] \\
\hline Peak 4 & ND & ND & {$[16.0,16.5]$} & {$[16.5]$} \\
\hline \multicolumn{5}{|l|}{ Concentration (ng/mL) } \\
\hline Peak 1 & $2.71 \pm 0.22^{\mathrm{a}}$ & $1.93 \pm 0.28^{\mathrm{b}}$ & $3.27 \pm 0.18$ & $3.64 \pm 0.40$ \\
\hline Peak 2 & $2.61 \pm 0.39$ & $2.99 \pm 0.32$ & $3.51 \pm 0.46$ & $3.58 \pm 0.55$ \\
\hline Peak 3 & $3.49 \pm 0.28$ & ND & $3.73 \pm 1.02$ & {$[2.54]$} \\
\hline Peak 4 & ND & ND & {$[3.11,4.21]$} & [3.66] \\
\hline \multicolumn{5}{|l|}{ Estradiol $\left(E_{2}\right)$ peak characteristics } \\
\hline No. of peaks (days $11.5-16.5$ ) & $3.2 \pm 0.2$ & $2.7 \pm 0.3$ & $2.9 \pm 0.3^{\mathrm{ac}}$ & $1.7 \pm 0.3^{\mathrm{bc}}$ \\
\hline \multicolumn{5}{|l|}{ Time of occurrence } \\
\hline Peak 1 & $11.9 \pm 0.08$ & $12.6 \pm 0.4$ & $11.7 \pm 0.3$ & $12.6 \pm 0.4$ \\
\hline Peak 2 & $13.7 \pm 0.2$ & $14.5 \pm 0.3$ & $13.8 \pm 0.5$ & $14.0 \pm 0.8$ \\
\hline Peak 3 & $15.0 \pm 0.3$ & $15.5 \pm 0.3$ & $15.4 \pm 0.4$ & {$[14.5]$} \\
\hline Peak 4 & {$[16.5]$} & {$[16.5]$} & [16.5] & ND \\
\hline \multicolumn{5}{|l|}{ Concentration (pg/mL) } \\
\hline Peak 1 & $9.64 \pm 0.36$ & $9.77 \pm 0.89$ & $3.19 \pm 0.49$ & $3.31 \pm 0.75$ \\
\hline Peak 2 & $10.21 \pm 0.74$ & $8.12 \pm 0.82$ & $4.05 \pm 0.70$ & $4.45 \pm 1.20$ \\
\hline Peak 3 & $9.50 \pm 1.32$ & $7.44 \pm 2.49$ & $4.55 \pm 1.04$ & [4.42] \\
\hline Peak 4 & [4.18] & {$[4.08]$} & [6.33] & ND \\
\hline
\end{tabular}

Abbreviation: ND, not detected.

${ }^{\mathrm{ab}} \mathrm{P}<0.05 ;{ }^{\mathrm{AB}} \mathrm{P}<0.01$.

Here, day $0=$ first ovulation of the estrous cycle studied. Data obtained for only 1 or 2 animals per group are shown in brackets. Data are expressed as mean \pm standard error of the mean.

c Mann-Whitney rank-sum test; day 0 = ovulation.

2 FSH peaks on days 1.5 and 3.9, whereas the control group of cyclic ewes only exhibited 1 FSH peak during the treatment period (on day 4.2; [5]). Therefore, creation of mid-cycle $\mathrm{P}_{4}$ concentrations early or late in the luteal phase of ewes increases the number of fluctuations in serum FSH concentrations. In the aforementioned study by Baby et al [5], serial $\mathrm{P}_{4}$ injections given early in metestrus advanced follicle wave emergence in treated compared with control ewes; as a result, $\mathrm{P}_{4}$-treated ewes had 1 more follicular wave compared with control ewes during the same time frame (days 0 to 6 from ovulation) [5]. Cyclic ewes with 4 follicular waves per estrous cycle (emerging on $\sim$ days 0,4 , 8 , and 12 after ovulation) also have higher serum $\mathrm{P}_{4}$ concentrations than their counterparts with 3 waves (emerging on $\sim$ days $0,5.5$, and 10) [4]. Injections of exogenous ovine FSH resulting in an additional FSH peak midway through the endogenous interpeak intervals in anestrous ewes consistently induced wave emergence $\sim 1 \mathrm{~d}$ after FSH peaks [6]. The characteristics of induced follicular waves did not differ from those of endogenous follicular waves (eg, mean duration of the growth phase spans $\sim 3 \mathrm{~d}[6])$. In the present study, an additional endogenous FSH peak detected approximately $2 \mathrm{~d}$ before the preovulatory discharge of gonadotropins in $\mathrm{P}_{4}$-treated ewes occurred too late to stimulate the growth of ovarian antral follicles to ovulatory sizes (follicle wave emergence) before the end of the interovulatory period studied. This notwithstanding, a decline in numbers of ovulating penultimate wave follicles in the treated ewes in this study does not seem to be caused by diminished FSH secretion. It is equally unlikely that changes in LH pulsatility affected the numbers of emerging antral follicles, as they normally do not vary among waves developing at different stages of the estrous cycle [2]. However, it is attractive to speculate that these ovarian effects of $\mathrm{P}_{4}$ late in diestrus are direct [27] and may involve transient alterations in follicular responsiveness to gonadotropic stimuli and/or biosynthesis of various locally acting promoters of antral follicle growth $[3,28]$; the underlying molecular mechanisms remain to be elucidated.

In the first experiment, $\mathrm{P}_{4}$-treated ewes exceeded control animals in circulating $\mathrm{E}_{2}$ concentrations $2.5 \mathrm{~d}$ after the second $\mathrm{P}_{4}$ dose (day 14.5). In cyclic ewes, the largest antral follicles of waves begin to produce $E_{2}$ at the time of emergence (ie, recruitment from the pool of 2 to $3-\mathrm{mm}$ follicles), and peak $E_{2}$ concentrations occur when the follicles reach their maximum diameters (ie, end of the growth phase; $[1,2])$. In both groups of animals, the end of follicular growth phase for the final wave of the cycle was observed between days 14 and 15 . There were no differences in mean numbers of large antral during that period, but treated ewes had more small antral follicles (3 $\mathrm{mm}$ in diameter) than controls. Therefore, the difference in serum $E_{2}$ concentrations in experiment 1 was most likely due to the difference in total numbers of ovarian antral follicles or transiently increased follicular estrogenicity in $\mathrm{P}_{4}$-treated ewes. In the second experiment, there were no significant differences in the numbers of ovarian follicles or growth 
Table 2

Comparisons of ovulation rates, estrous cycle duration, and follicle wave characteristics (penultimate and final wave of the interovulatory interval studied) between progesterone $\left(\mathrm{P}_{4}\right)$-treated ewes and their respective controls in experiment 1 (moderately prolific cross-bred ewes) and experiment 2 (highly prolific Olkuska sheep).

\begin{tabular}{|c|c|c|c|c|}
\hline \multirow[t]{2}{*}{ Variables } & \multicolumn{2}{|c|}{$\begin{array}{l}\text { Experiment } 1 \text { (Rideau Arcott } \times \text { Polled } \\
\text { Dorset) }\end{array}$} & \multicolumn{2}{|c|}{ Experiment 2 (Olkuska) } \\
\hline & Treatment $(\mathrm{n}=8)$ & Control $(\mathrm{n}=8)$ & Treatment $(\mathrm{n}=7)$ & Control $(n=7)$ \\
\hline Ovulation rate\#1 & $2.8 \pm 0.3$ & $2.8 \pm 0.2$ & $4.0 \pm 1.0$ & $3.7 \pm 0.6$ \\
\hline Ovulation rate\#2 (post-treatment) & $1.6 \pm 0.2^{\mathrm{A}}$ & $3.2 \pm 0.4^{\mathrm{B}}$ & $3.2 \pm 0.8^{\mathrm{c}}$ & $4.0 \pm 1.0^{c}$ \\
\hline No. of luteal structures post-treatment & $1.5 \pm 0.2^{\mathrm{A}}$ & $3.1 \pm 0.3^{\mathrm{B}}$ & $3.2 \pm 0.8^{c}$ & $4.0 \pm 1.0^{c}$ \\
\hline Interovulatory interval (d) & $17.3 \pm 0.4$ & $16.6 \pm 0.1$ & $16.9 \pm 0.6$ & $16.3 \pm 0.8$ \\
\hline \multicolumn{5}{|l|}{ Penultimate wave } \\
\hline $\begin{array}{l}\text { Day of emergence (Day } 0=\text { first ovulation of } \\
\text { the estrous cycle studied) }\end{array}$ & $9.6 \pm 0.4$ & $9.9 \pm 0.3$ & $10.1 \pm 0.3$ & $9.6 \pm 0.2$ \\
\hline No. of follicles & $1.4 \pm 0.2^{\mathrm{ac}}$ & $2.1 \pm 0.3^{\mathrm{bc}}$ & $3.2 \pm 0.2$ & $3.2 \pm 0.5$ \\
\hline No. of ovulatory follicles & $0.25 \pm 0.16^{\mathrm{Ac}}$ & $1.75 \pm 0.45^{\mathrm{Bc}}$ & $0.5 \pm 0.3^{\mathrm{ac}}$ & $1.6 \pm 0.4^{\mathrm{bc}}$ \\
\hline$\%$ of ovulating follicles & $25.0 \pm 16.4^{\mathrm{ac}}$ & $75.0 \pm 16.4^{\mathrm{bc}}$ & $14.8 \pm 9.0^{\mathrm{a}}$ & $53.4 \pm 16.7^{b}$ \\
\hline Duration of the growth phase (d) & $2.9 \pm 0.6$ & $3.6 \pm 0.3$ & $2.4 \pm 0.2^{\mathrm{c}}$ & $3.6 \pm 0.6^{c}$ \\
\hline Growth rate $(\mathrm{mm} / \mathrm{d})$ & $1.1 \pm 0.2^{\mathrm{ac}}$ & $0.78 \pm 0.05^{\mathrm{bc}}$ & $1.4 \pm 0.2^{\mathrm{a}}$ & $0.90 \pm 0.04^{b}$ \\
\hline Duration of the static phase $(\mathrm{d})$ & $2.0 \pm 0.6$ & $2.9 \pm 0.4$ & $2.3 \pm 0.4$ & $2.8 \pm 0.7$ \\
\hline Duration of the regressing phase (d) & $2.0 \pm 0.3$ & $1.7 \pm 0.2$ & $1.8 \pm 0.6$ & $1.1 \pm 0.1$ \\
\hline Regression rate $(\mathrm{mm} / \mathrm{d})$ & $1.2 \pm 0.2$ & $1.1 \pm 0.1$ & $1.4 \pm 0.2^{\mathrm{a}}$ & $0.8 \pm 0.1^{b}$ \\
\hline Maximum follicle diameter (MaxFD) (mm) & $5.7 \pm 0.3^{c}$ & $5.4 \pm 0.1^{\mathrm{c}}$ & $5.6 \pm 0.2$ & $6.1 \pm 0.6$ \\
\hline Mean day achieving MaxFD & $11.9 \pm 0.6$ & $13.6 \pm 0.6$ & $12.5 \pm 0.5$ & $13.3 \pm 0.7$ \\
\hline Ovulatory follicle diameter (mm) & $6.5 \pm 0.5^{\mathrm{ac}}$ & $5.3 \pm 0.1^{\mathrm{bc}}$ & $6.0 \pm 1.0$ & $6.4 \pm 0.5$ \\
\hline \multicolumn{5}{|l|}{ Final wave } \\
\hline Day of emergence & $12.4 \pm 0.4$ & $12.6 \pm 0.4$ & $11.8 \pm 0.6$ & $12.2 \pm 0.6$ \\
\hline No. of follicles & $1.5 \pm 0.3$ & $1.7 \pm 0.3$ & $3.7 \pm 0.6$ & $2.6 \pm 0.9$ \\
\hline No. of ovulatory follicles & $1.4 \pm 0.2$ & $1.6 \pm 0.3$ & $2.6 \pm 0.6$ & $2.6 \pm 0.8$ \\
\hline$\%$ of ovulatory follicles & $95.9 \pm 4.1$ & $93.8 \pm 6.3$ & $73.8 \pm 9.6$ & $93.4 \pm 6.6$ \\
\hline Duration of the growth phase (d) & $3.3 \pm 0.4$ & $2.5 \pm 0.3$ & $2.7 \pm 0.4$ & $2.7 \pm 0.5$ \\
\hline Growth rate $(\mathrm{mm} / \mathrm{d})$ & $1.0 \pm 0.1^{\mathrm{c}}$ & $1.1 \pm 0.1^{\mathrm{c}}$ & $1.3 \pm 0.1^{\mathrm{c}}$ & $1.3 \pm 0.3^{c}$ \\
\hline Duration of the static phase (d) & $2.7 \pm 0.3$ & $2.4 \pm 0.3$ & $2.1 \pm 0.1$ & $2.1 \pm 0.05$ \\
\hline Duration of the regressing phase (d) & {$[2.0]$} & {$[2.0]$} & {$[1.0,1.0,2.0]$} & {$[2.0]$} \\
\hline Regression rate $(\mathrm{mm} / \mathrm{d})$ & {$[1.0]$} & {$[1.0]$} & {$[2.0,2.5,1.0]$} & {$[2.0]$} \\
\hline Maximum follicle diameter (MaxFD) (mm) & $5.8 \pm 0.2^{c}$ & $5.7 \pm 0.2^{c}$ & $6.0 \pm 0.3$ & $5.5 \pm 0.3$ \\
\hline Mean day achieving MaxFD & $15.1 \pm 0.3^{c}$ & $14.8 \pm 0.3^{c}$ & $14.7 \pm 0.6$ & $14.6 \pm 0.5$ \\
\hline Ovulatory follicle diameter (mm) & $5.8 \pm 0.2$ & $5.7 \pm 0.3$ & $6.0 \pm 0.3$ & $5.5 \pm 0.4$ \\
\hline Inter-wave interval (d) & $3.1 \pm 0.3$ & $3.1 \pm 0.3$ & $2.4 \pm 0.7$ & $3.0 \pm 0.5$ \\
\hline
\end{tabular}

Data are expressed as mean \pm standard error of the mean.

${ }^{\mathrm{ab}} \mathrm{P}<0.05 ;{ }^{\mathrm{AB}} \mathrm{P}<0.01$.

c Mann-Whitney rank-sum test.

kinetics of the last follicular wave of the cycle between the 2 groups of ewes; consequently, serum $\mathrm{E}_{2}$ concentrations were similar in both subsets of ewes although the treatment group exhibited more frequent peaks in mean $E_{2}$ levels. The latter could be attributed to an occurrence of an additional preovulatory peak in blood $E_{2}$ concentrations (detected on $\sim$ day 15.5 ) in a majority of $\mathrm{P}_{4}$-treated Olkuska sheep. The specific reason for these alterations in $\mathrm{E}_{2}$ release before estrus and ovulations in the treated animals in experiment 2 remains uncertain.

In both experiments, the treatment with exogenous $\mathrm{P}_{4}$ significantly increased the growth rate of large antral follicles and reduced the number and percentage of ovulatory follicles emerging in the penultimate wave of the estrous cycle studied. However, the total number of follicles attaining $\geq 5 \mathrm{~mm}$ in size in the penultimate wave of the cycle was decreased in $\mathrm{P}_{4}$-treated Rideau Arcott $\times$ Polled Dorset ewes but not in Olkuska sheep. Albeit the difference was not statistically significant, due mainly to relatively high individual variability, $\mathrm{P}_{4}$-treated Olkuska ewes had on the average 1 follicle more in the final wave of the cycle than controls. Consequently, the mean ovulation rate was only decreased in moderately prolific cross-bred ewes receiving $\mathrm{P}_{4}$ injections at the end of diestrus. Clearly, differences do exist in the endocrine control of antral follicle development between highly and moderately prolific breeds of sheep. The latter observation is further supported by dissimilar effects of $\mathrm{P}_{4}$ treatment on the regression rate of large antral follicles (increased in $\mathrm{P}_{4}$-treated Olkuska sheep but not in cross-bred ewes) and maximum diameter of ovulating follicles from the penultimate wave (greater in $\mathrm{P}_{4}$-treated Rideau Arcott $\times$ Polled Dorset ewes but not in Olkuska breed) as well as the number of 3-mm follicles post-treatment (increased in $\mathrm{P}_{4}$-treated Rideau Arcott $\times$ Polled Dorset sheep from days 15 to 17). The reasons for these differences remain equivocal. Apart from a rise in mean daily numbers of $3-\mathrm{mm}$ follicles in experiment 1 , there was no apparent effect of $\mathrm{P}_{4}$ treatment on antral follicle populations in the ewes of the present study.

The present results may pave the way to the development of simple, practical methods to control sheep fertility, using protocols that mimic a physiological luteal mechanism. Treatment with exogenous $\mathrm{P}_{4}$ can be employed to temporarily reduce the incidence of twinning or triplet pregnancies in moderately prolific strains of sheep; this would help control the incidence of twin-lamb disease 
A
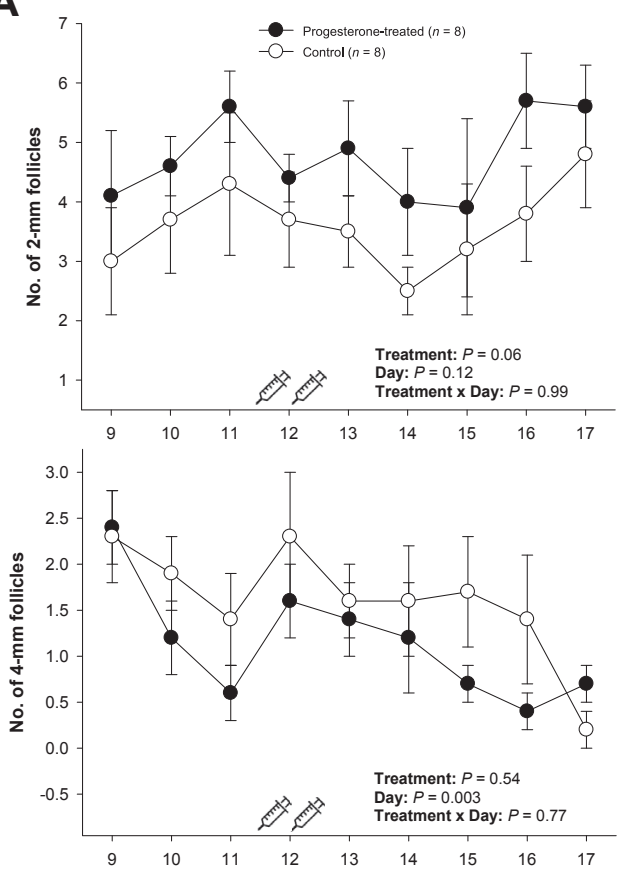

EXPERIMENT 1
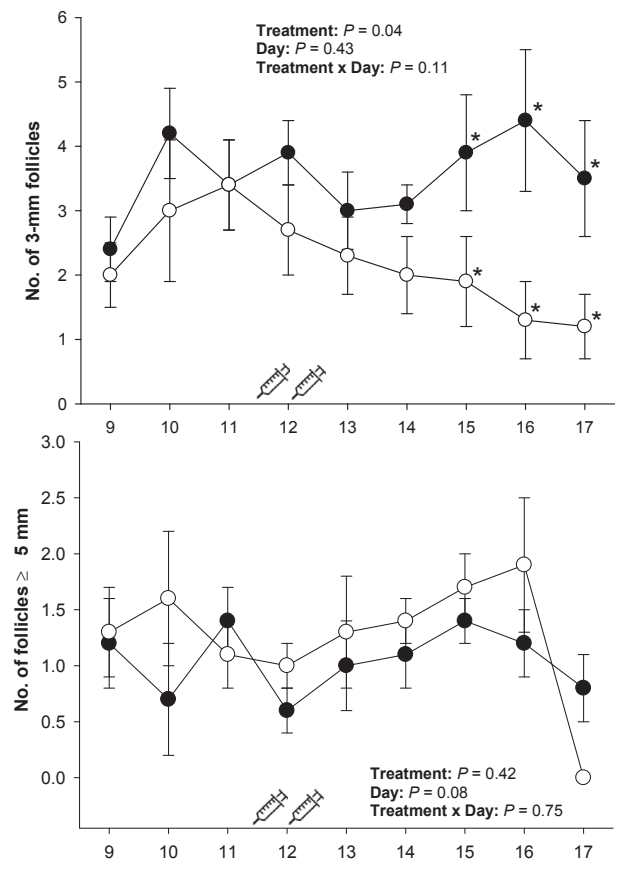

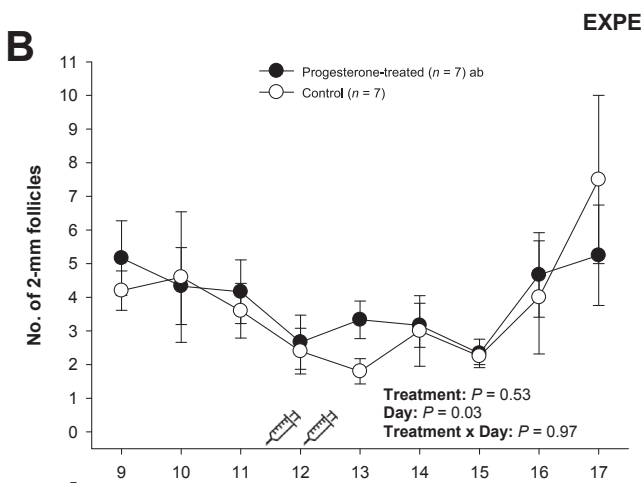

EXPERIMENT 2
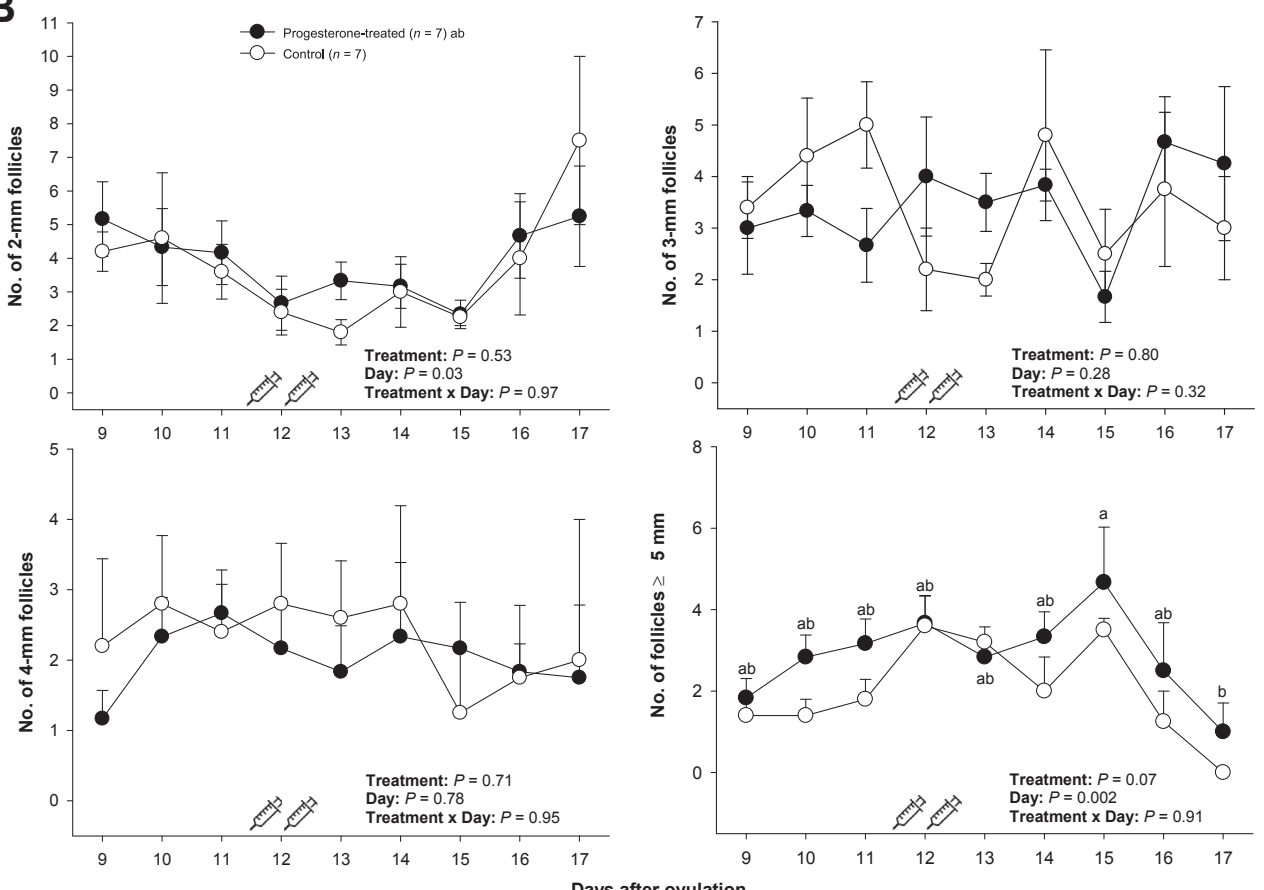

Fig. 2. Daily numbers (mean \pm standard error of the mean) of ovarian antral follicles in different size categories in ultrasonographically monitored moderately prolific Rideau Arcott $\times$ Poled Dorset ewes (A: Experiment 1 ) and highly prolific Olkuska sheep (B: Experiment 2) that received progesterone (progesterone-treated) or vehicle injections (control) on day 11 at PM and day 12 at AM. (day $0=$ first ovulation of the estrous cycle studied). Syringe symbols along the $\mathrm{X}$-axis denote the timing of progesterone injections. Asterisks indicate the differences $(P<0.05)$ between groups, and different letters denote significant differences over time.

(pregnancy toxemia) and underfed suckling lambs. Alternatively, manipulating circulating concentrations of $\mathrm{P}_{4}$ using prostaglandins or oxytocin, with or without $\mathrm{P}_{4}$-releasing pessaries, or application of $\mathrm{P}_{4}$ antagonists could be used to improve fertility in nonprolific ewes. If administering $\mathrm{P}_{4}$ late in the cycle reduces ovulation rates in moderately prolific breeds of sheep, it is very likely that reducing $\mathrm{P}_{4}$ concentrations or blocking its effects at the end 
of diestrus may increase ovulation rates in nonprolific ewes. Future studies are required to determine the optimal timing and doses of exogenous hormones or chemicals.

In summary, the present study demonstrates that prolific ewes treated with $\mathrm{P}_{4}$ at the end of diestrus had a significantly lower percentage of follicles ovulating from the penultimate wave of the estrous cycle. Moreover, exogenous $\mathrm{P}_{4}$ given to moderately prolific Rideau Arcott $\times$ Polled Dorset ewes reduced the number of ovulatory-sized antral follicles in the wave in which the treatment was applied. As a result, the moderately prolific sheep receiving $\mathrm{P}_{4}$ injection on days 11 and 12 postovulation had a reduced ovulation rate compared with untreated controls. These observations can be interpreted to suggest that $\mathrm{P}_{4}$ is an important endocrine signal governing antral follicular development and ovulation rate in sheep, and that differences exist in the endocrine control of antral follicle development between prolific and nonprolific genotypes as well as between moderately and highly prolific strains of sheep. Our results also show that ovulation rates in cyclic ewes can be artificially manipulated. Finally, the present observations in cyclic ewes provide the basis for further investigations into whether similar biological mechanisms governing the ovulation rate are conserved among other polyovulatory species or if manipulating the luteal function can lead to multiple ovulations and twinning in monovulatory species.

\section{Acknowledgments}

The authors would like to extend their thanks to Ms Susan Cook for her excellent technical assistance with hormone assays. This study was funded by the Natural Sciences and Engineering Research Council of Canada (PMB), and the Department of Animal Biotechnology (formerly the Department of Swine and Small Ruminant Breeding) of the Agricultural University of Kraków, Cracow, Poland (2013-14). The present results were presented, in the preliminary form, at the 41st Annual Conference of the International Embryo Transfer Society in Versailles, France (January 10-13, 2015; Abstract \#178). The authors have no conflicts of interest to declare.

\section{References}

[1] Bartlewski PM, Baby TE, Giffin JL. Reproductive cycles in sheep. Anim Reprod Sci 2011;124:259-68.

[2] Bartlewski PM, Beard AP, Cook SJ, Chandolia RK, Honaramooz A, Rawlings NC. Ovarian antral follicular dynamic and their relationships with endocrine variables throughout the oestrous cycle in breeds of sheep differing in prolificacy. J Reprod Fertil 1999;115: $111-24$.

[3] Monestier O, Servin B, Auclair S, Bourquard T, Poupon A, Pascal G, Fabre S. Evolutionary origin of bone morphogenetic protein 15 and growth and differentiation factor 9 and differential selective pressure between mono- and poly-ovulating species. Biol Reprod 2014; 91:1-13.

[4] Baby TE, Bartlewski PM. Circulating concentrations of ovarian steroids and follicle-stimulating hormone (FSH) in ewes with 3 or 4 waves of antral follicle emergence per estrous cycle. Reprod Biol 2011;11:19-36.

[5] Baby TE, Bartlewski PM. Progesterone as the driving regulatory force behind serum FSH concentrations and antral follicular development in cycling ewes. Reprod Fertil Dev 2011;23:303-10.
[6] Duggavathi R, Bartlewski PM, Agg E, Flint S, Barrett DMW Rawlings NC. The effect of the manipulation of FSH-peak characteristics on follicular wave dynamics in sheep: does an ovarianindependent endogenous rhythm in FSH secretion exist? Biol Reprod 2005;72:1466-74.

[7] Gonzalez-Bulnes A, Souza CJ, Campbell BK, Baird DT. Systemic and intraovarian effects of dominant follicles on ovine follicular growth. Anim Reprod Sci 2004;84:107-19.

[8] Gibbons JR, Kot K, Thomas DL, Wiltbank MC, Ginther OJ. Follicular and FSH dynamics in ewes with a history of high and low ovulation rates. Theriogenology 1999;52:1005-20.

[9] Evans ACO. Ovarian follicle growth and consequences for fertility in sheep. Anim Reprod Sci 2003;78:289-306.

[10] Bartlewski PM, Beard AP, Rawlings NC. An ultrasonographic study of luteal function in breeds of sheep with different ovulation rates. Theriogenology 1999;52:115-30.

[11] Davies KL, Bartlewski PM, Pierson RA, Rawlings NC. Computer-assisted image analyses of corpora lutea in relation to peripheral concentrations of progesterone: a comparison between breeds of sheep with different ovulation rates. Anim Reprod Sci 2006;96:165-75.

[12] Gallienne J, Gregg C, LeBlanc E, Yaakob N, Wu D, Davies K, Rawlings N, Pierson R, Deardon R, Bartlewski PM. Correlations between ultrasonographic characteristics of corpora lutea and systemic concentrations of progesterone during the discrete stages of corpora lutea lifespan and secretory activity in cyclic ewes. Exp Biol Med 2012;237:509-15.

[13] Shrestha JNB, Heaney DP. Review of Canadian, Outaouais and Rideau Arcott breeds of sheep: 1. Development and characterization. Small Ruminant Res 2003;49:79-96.

[14] Zieba DA, Murawski MG, Wierzchos E. The role of luteal steroid hormones in the regulation of the estrous cycle of high fecundity Olkuska sheep. Anim Reprod Sci 2000;58:87-98.

[15] Zieba DA, Murawski M, Schwarz T, Wierzchos E. Pattern of follicular development in high fecundity Olkuska ewes during the estrous cycle. Reprod Biol 2002;2:39-58.

[16] Szczepanski W, Milewski S, Brzostowski H, Tanski Z, CzreniawskaZajac S. Detection of oestrus and pregnancy in sheep basing on electrical resistance of vaginal mucus (in Polish with English abstract). Acta Academiae Agriculturae ac Technicae Olstenesis 1994; 41:127-34.

[17] Bartlewski PM, Beard AP, Rawlings NC. The relationship between vaginal impedance and serum concentrations of estradiol and progesterone throughout the sheep estrous cycle. Theriogenology 1999;51:813-28.

[18] Duggavathi R, Bartlewski PM, Pierson RA, Rawlings NC. Luteogenesis in cyclic ewes: echotextural, histological and functional correlates. Biol Reprod 2003;69:634-9.

[19] Currie WD, Rawlings NC. Prolonged infusion of morphine and naloxone in the ewe: fluctuations in responsiveness of LH and lack of responsiveness of FSH. J Reprod Fertil 1989;86:359-66.

[20] Rawlings NC, Jeffecoate IA, Howell WE. Response of purebred and crossbred ewes to intensified management. J Anim Sci 1987;65: 651-7.

[21] Joseph IBJK, Currie WD, Rawlings NC. Effects of time after ovariectomy, season and oestradiol on luteinizing hormone and folliclestimulating hormone secretion in ovariectomized ewes. J Reprod Fertil 1992;94:511-23.

[22] Norms: Nutrient requirements for cattle and sheep in the traditional system (in Polish). 6th rev. ed. Poland: IZ Krakow; 1993.

[23] Pohler KG, Pereira MHC, Lopes FR, Lawrence JC, Keisler DH, Smith MF, Vasconcelos JLM, Green JA. Circulating concentrations of bovine pregnancy associated glycoproteins and late embryonic mortality in lactating dairy herds. J Dairy Sci 2015;99:1-11.

[24] Rozell TG, Keisler DH. Effects of oestradiol on LH, FSH and prolactin in ovariectomized ewes. J Reprod Fertil 1990;88:645-53.

[25] Clifton DK, Steiner RA. Cycle detection: a technique for estimating the frequency and amplitude of episodic fluctuations in blood hormone and substrate concentrations. Endocrinology 1983;112: 1057-64.

[26] Cochran WG, Cox GM. Experimental designs. 2nd ed. New York: Wiley and Sons; 1957.

[27] Juengel JL, Heath DA, Quirke LD, McNatty KP. Oestrogen receptor alpha and beta, androgen receptor and progesterone receptor mRNA and protein localisation within the developing ovary and in small growing follicles of sheep. Reproduction 2006;131: 81-92.

[28] Campbell BK. The endocrine and local control of ovarian follicle development in the ewe. Anim Reprod 2009;6:159-71. 